\title{
UPAYA MENINGKATKAN HASIL BELAJAR MATEMATIKA DENGAN MODEL PEMBELAJARAN KOOPERATIF TIPESTAD DI KELAS III SD NEGERI NO. 056591 SIDOREJO
}

\author{
Suwartik \\ Surel: zahratazkia06@gmail.com
}

\begin{abstract}
ABSTRAK
Penelitian ini bertujuan untuk mengetahui peningkatan hasil belajar dan aktivitas belajar matematika siswa dengan model koperatif tipe STAD di kelas III SD Negeri No. 056591 Sidorejo Tahun Pelajaran 2015/2016. Subjek penelitian yaitu siswa kelas III SD Negeri No. 056591 Sidorejo berjumlah 15 orang. Dari hasil penelitian disimpulkan bahwa; 1) Dengan model STAD, hasil belajar siswa meningkat yaitu siklus I terdapat 8 siswa yang tuntas secara individu tetapi kelas belum tuntas sedangkan pada siklus II terdapat 13 siswa yang tuntas secara individu dan tuntas secara kelas; 2) Terjadi peningkatan rata-rata aktivitas belajar, yaitu aktivitas mengerjakan LAS dari $27 \%$ menjadi $38 \%$ dan bertanya pada teman dari $11 \%$ menjadi $24 \%$, sedangkan aktivitas yang menurun adalah menulis/ membaca dari 39\% menjadi $27 \%$, aktivitas aktivitas bertanya pada guru dari $13 \%$ menjadi $9 \%$ dan aktivitas yang tidak relevan dengan KBM dari $11 \%$ menjadi $3 \%$.
\end{abstract}

Kata Kunci : Student Team Achievement Division (STAD), Hasil Belajar Siswa, Aktivitas Belajar

\section{PENDAHULUAN}

Berdasarkan pengalaman mengajar selama lebih kurang 34 tahun sebagai guru kelas di SD. Negeri No. 056591 Sidorejo, banyak ditemukan permasalahan khususnya pada mata pelajaran matematika pada saat kegiatan belajar mengajar berlangsung yang menyebabkan tujuan pembelajaran tidak tercapai. Untuk mengatasi permasalahan tersebut, peneliti mengikuti seminar/workshop, setelah mengikutinya dan menerapkannya dalam kegiatan belajar mengajar, ternyata belum menbuahkan hasil dimana siswa kelas III masih kesulitan dalam memahami materi pecahan sederhana. Hal ini terlihat dari rata-rata hasil ujian siswa kelas III SD. Negeri No. 056591 Sidorejo yang masih berada di bawah KKM yang telah ditentukan sekolah.

Permasalahan yang peneliti hadapi ketika mengajarkan siswa kelas III adalah kurangnya persiapan siswa ketika memulai pembelajaran, dimana siswa tidak belajar terlebih dahulu di rumah sebelum pergi ke sekolah dan hanya menunggu penjelasan materi dari gurunya, sehingga ketika guru bertanya, tidak ada siswa yang mampu menjawab dengan alasan belum dipelajari padahal jawabannya ada di dalam buku paket. Setelah diberikan penjelasan, peneliti selalu memberikan pertanyaan atau contoh 
soal di papan tulis kepada siswa untuk mengecek pemahaman siswa, dari 15 siswa ternyata hanya 3 siswa yang mau mengajukan diri untuk menjawab pertanyaan peneliti, 4 siswa yang mau menjawab tetapi mesti ditunjuk sedangkan sisanya hanya menunggu jawaban teman atau guru. Selain itu, pada saat pengerjaan soal sering ditemukan siswa yang lupa menyamakan penyebut pada saat menjumlahkan pecahan sehingga mereka langsung menjumlahkan penyebut dengan penyebut dan pembilang dengan pembilang. Hal ini juga disebabkan karena pada saat pembelajaran berlangsung, sebagian siswa main-main dalam belajar sehingga apa yang disampaikan gurunya tidak dapat dipahami oleh siswa.

$\begin{array}{llr}\text { Dengan } & \text { adanya deskripsi } \\ \text { diatas, maka } & \text { diperlukan } & \text { suatu } \\ \text { pembenahan } & \text { dalam } & \text { upaya }\end{array}$ meningkatkan hasil belajar siswa dengan melakukan perbaikan pada aktivitas belajar siswa. Salah satu cara membenahinya yaitu dengan menerapkan suatu model pembelajaran yang dapat membuat siswa berdiskusi, berpikir kritis, berani dan mau mengambil tanggung jawab untuk pembelajaran mereka sendiri Salah sattu model yang cocok dengan permasalahan di atas adalah model pembelajaran kooperatif tipe STAD.

Berdasarkan latar belakang di atas, maka yang menjadi rumusan masalah dalam penelitian ini adalah; 1) Apakah terjadi peningkatan hasil belajar siswa dengan menerapkan model pembelajaran Student Teams Achievement Division di kelas III SD. Negeri No. 056591 Sidorejo? 2) Apakah terjadi peningkatan aktivitas belajar siswa dengan menerapkan model pembelajaran Student Teams Achievement Division di kelas III SD. Negeri No. 056591 Sidorejo?

Berdasarkan rumusan masalah di atas, maka tujuan penelitian ini adalah untuk; 1) Untuk mengetahui apakah terjadi peningkatan hasil belajar siswa dengan menerapkan model pembelajaran Student Teams Achievement Division di kelas III SD. Negeri No. 056591 Sidorejo; 2) Untuk mengetahui apakah terjadi peningkatan aktivitas belajar siswa dengan menerapkan model pembelajaran Student Teams Achievement Division di kelas III SD. Negeri No. 056591 Sidorejo.

Menurut Lie (2008) bahwa model pembelajaran Cooperative Learning tidak sama dengan sekadar belajar kelompok, tetapi ada unsurunsur dasar yang membedakannya dengan pembagian kelompok yang dilakukan asal-asalan. Roger dan David Johnson mengatakan bahwa tidak semua kerja kelompok bisa dianggap Cooperative Learning, untuk itu harus diterapkan lima unsur model pembelajaran gotong royong yaitu saling ketergantungan positif, tanggungjawab perseorangan, tatap 
muka, pembelajaran secara tim, didasarkan pada manajemen kooperatif, kemauan untuk bekerjasama dan keterampilan bekerjasama.

Model pembelajaran kooperatif tipe STAD (Student Team Achivement Division) merupakan salah satu metode pembelajaran kelompok yang paling awal ditemukan. Metode ini sangat populer dikalangan para ahli pendidikan. Dalam metode STAD siswa dipasangkan secara merata yang memiliki kemampuan tinggi dan rendah dalam suatu kelompok sebanyak $4-5$ orang. Skor kelompok diberikan berdasarkan atas prestasi anggota kelompoknya. Ciri-ciri yang penting dalam STAD adalah bahwa siswa dihargai atas prestasi kelompok dan juga terhadap semangat kelompok untuk bekerjasama.

Pembelajaran kooperatif tipe STAD terdiri dari lima komponen utama, yaitu : pengajaran kelas, belajar time tes atau kuis, skor peningkatan individu dan pengakuan kelompok (Slavin, 2005).

a. Pengajaran

b. Belajar dalam tim

c. Tes

d. Skor Peningkatan Individu

\section{METODE PENELITIAN}

Penelitian ini dilakukan di SD Negeri No. 056591 Sidorejo yang beralamat di Jalan Letjend Jamin Ginting Desa Sidorejo dan pelaksanaannya selama 4 bulan mulai dari bulan Februari sampai dengan Mei 2016.

Subjek penelitian adalah siswa kelas III SD Negeri No. 056591 Sidorejo Tahun Pembelajaran 2015/2016 dengan jumlah siswa yang terikut dalam penelitian sebanyak 15 siswa.

Alat pengumpul data dalam penelitian ini adalah: lembar observasi untuk mengetahui aktivitas belajar siswa dan tes hasil belajar untuk mengetahui kemampuan kognitif siswa.

Penelitian ini berbentuk Penelitian Tindakan Kelas (PTK). PTK pertama kali diperkenalkanoleh psikologi sosial Amerika yang bernama Kurt Lewin pada tahun 1946 (Aqib, 2006 :13). Penelitian tindakan kelas adalah penelitian yang dilakukan oleh guru di kelas atau disekolah dengan penekanan pada penyempurnaan atau peningkatan proses pembelajaran. Menurut Lewin dalam Aqib (2006 : 21) menyatakan bahwa dalam satu siklus terdiri atas empat langkah, yaitu perencanaan (planning), tindakan (acting), observasi (observing) dan refleksi (reflecting).

Metode analisis data pada penelitian ini digunakan metode deskriptif dengan membandingkan hasil belajar siswa sebelum tindakan dengan hasil belajar siswa setelah tindakan. 
Langkah-langkah pengolahan data sebagai berikut:

1. Untuk menilai ulangan atau tes formatif

Melakukan penjumlahan nilai yang diperoleh siswa, yang selanjutnya dibagi dengan jumlah siswa yang ada di kelas tersebut sehingga diperoleh rata-rata tes formatif dapat dirumuskan:

$$
\bar{X}=\frac{\sum X}{\sum N}
$$

Dengan :

$$
\begin{aligned}
\bar{X} & =\text { Nilai rata-rata } \\
\Sigma \mathrm{X} & =\text { Jumlah semua nilai siswa } \\
\Sigma \mathrm{N} & =\text { Jumlah siswa }
\end{aligned}
$$

\section{Untuk ketuntasan belajar}

Ada dua kategori ketuntasan belajar yaitu secara perorangan dan secara klasikal. Seorang siswa telah tuntas belajar bila telah mencapai skor $\geq \mathrm{KKM}$ yang telah ditetapkan sekolah untuk matematika kelas III sebesar 75, dan kelas disebut tuntas belajar bila di kelas tersebut terdapat $85 \%$ yang telah mencapai daya serap lebih dari atau sama dengan KKM. Untuk menghitung persentase ketuntasan belajar digunakan rumus sebagai berikut:

$$
P=\frac{\sum \text { Siswa.yang.tuntas.belajar }}{\sum \text { Siswa }} \times 100 \%
$$

Sebagai tolak ukur peningkatan hasil belajar siswa sesuai dengan rumusan masalah pada bab I dapat dilihat dari hasil formatif I dan formatif II secara individu dan kelas.

3. Untuk lembar observasi aktivitas siswa

Untuk mnghitung lembar observasi aktivitas siswa digunakan rumus sebagai berikut:

$$
\begin{aligned}
\% & =\frac{\bar{X}}{\sum X} x 100 \% \text { dengan } \\
\bar{X} & =\frac{\text { jumlah.hasil.pengamatan }}{\text { jumlah.pengamat }}=\frac{P_{1}+P_{2}}{2}
\end{aligned}
$$

Dimana:

$\%=$ Persentase angket

$\bar{X} \quad=$ Rata-rata

$\sum \bar{X}=$ Jumlah rata-rata

$\mathrm{P}_{1}=$ Pengamat 1

$\mathrm{P}_{2} \quad=$ Pengamat 2

Sebagai tolak ukur peningkatan aktivitas belajar siswa yang sesuai dengan rumusan masalah dapat dilihat dari meningkatnya ratarata aktivitas mengerjakan LAS, bertanya pada teman dan penurunan aktivitas membaca, bertanya pada guru dan kegiatan yang tidak relevan dengan KBM.

Berkaitan dengan indikator kinerja Suwandi dan Madyo Eko Susilo (2007:36) menyatakan bahwa "Indikator kinerja merupakan rumusan kinerja yang akan dijadikan dalam menentukan keberhasilan atau keefektifan penelitian. Dalam penelitian ini indikator pencapaian apabila nilai siswa secara individu mencapai KKM matematika kelas III yang ditetapkan sekolah sebesar 75 dan secara klasikal $\geq 85 \%$ siswa 
mencapai KKM tersebut.

\section{HASIL DAN PEMBAHASAN}

Penelitian ini dilaksanakan dalam dua siklus. Masing-masing siklus dilaksanakan dua kali pertemuan, pertemuan digunakan untuk pembahasan materi dengan alokasi waktu 2 x 35 menit, dan sebagian pertemuan akhir siklus digunakan untuk evaluasi dengan alokasi waktu 10 menit. Hal ini disesuaikan dengan jadwal pelajaran matematika.

Sebelum dilaksanakan Siklus I dilakukan uji awal untuk menjajaki kemampuan awal siswa. Hasil pretes menunjukkan nilai dengan rata-rata 20 dan nilai terendah 0 diperoleh 1 orang siswa dan tertinggi 30 diperoleh 6 orang siswa. Dengan ketuntasan minimal (KKM) sebesar 75 maka ketuntasan klasikal hanya sebesar 0\%.

Pada akhir siklus I dilakukan tes Formatif I untuk mengetahui kemampuan siswa dalam memahami materi pada siklus I. Nilai hasil Formatif I dalam Siklus I disajikan dalam Tabel 4.1.

Tabel 4.1 Deskripsi Data Formatif I

\begin{tabular}{|c|c|c|}
\hline Nilai & Frekuensi & Rata-rata \\
\hline 40 & 3 & \multirow{2}{*}{6} \\
\cline { 1 - 2 } 60 & 4 & \\
\hline 80 & 6 & \\
\hline 100 & 2 & \\
\hline Jumlah & 15 & \\
\hline
\end{tabular}

Siklus I dilakukan selama dua KBM yaitu KBM I dan KBM II. Pada saat melaksanakan pembelajaran dua pengamat merekam aktivitas siswa sesuai dengan instruksi oleh peneliti. Hasil rekaman yang dilakukan oleh pengamat diserahkan kembali kepada peneliti untuk dianalisis. Hasil analisis rekaman aktivitas siswa dari pengamat selama siklus I dapat disajikan dalam Tabel 4.2.

Tabel 4.2. Skor Rata-Rata Aktivitas Belajar Siswa Siklus I

\begin{tabular}{|c|l|c|c|}
\hline No & \multicolumn{1}{|c|}{ Aktivitas } & Skor & Proporsi \\
\hline 1 & Menulis/membaca & 20 & $39 \%$ \\
\hline 2 & Mengerjakan LAS & 13 & $27 \%$ \\
\hline 3 & Bertanya pada teman & 6 & $11 \%$ \\
\hline 4 & Bertanya pada guru & 6 & $13 \%$ \\
\hline 5 & $\begin{array}{l}\text { Yang tidak relevan } \\
\text { dengan KBM }\end{array}$ & 6 & $11 \%$ \\
\hline \multicolumn{2}{|c|}{ JUMLAH } & 50 & $100.00 \%$ \\
\hline
\end{tabular}

Merujuk pada hasil belajar, aktivitas belajar dan dokumentasi penelitian, belum tercapainya hasil belajar siswa pada ketuntasan klasikal disebabkan oleh :

1. Sebagian siswa masih belum terbiasa dengan alur pembelajaran atau masih bingung selama pelaksanaan kegiatan.

2. Sebagian siswa belum memiliki rasa tanggung jawab terhadap tugasnya dalam kelompok, di setiap kelompok siswa masih ada anggota kelompok yang menyerahkan permasalahan kepada anggota kelompoknya 
dan tidak mau tau, bahkan ada beberapa siswa yang menciptakan kegaduhan dalam kelompoknya.

3. Terlalu singkat waktu diskusi yang diberikan sehingga aktivitas diskusi tampak terburu-buru, apalagi waktu diskusi terpakai untuk kelompok mempelajari LAS, sehingga waktu pengerjaan LAS semakin sedikit.

4. Masih terjadi kesalahankesalahan dalam mengerjaan LAS dan penarikan kesimpulan oleh siswa yang menandakan terjadi miskonsepsi dalam diskusi kelompok.

Sebelum melanjutkan ke siklus II terlebih dahulu dilakukan perbaikan, perbaikan diperoleh melalui diskusi dengan guru sejawat. Adapun perbaikan yang dilakukan pada siklus II yaitu:

1. Untuk membantu siswa menyesuaikan diri dalam alur pembelajaran maka sebelum pembelajaran berlangsung guru akan menjelaskan terlebih dahulu desain pembelajaran sesuai dengan model pembelajaran kooperatif tipe STAD.

2. Untuk memunculkan rasa tanggung jawab masing-masing siswa maka tiap kelompok dibantu dalam membagi spesifikasi siswa dalam tugas masing-masing dan memberi peringatan bahwa tiap siswa akan ditagih pekerjaanya dalam kegiatan bertanya.

3. Untuk menyiasati masalah waktu, maka guru akan membagikan LAS sebelum KBM dilaksanakan. Hal ini agar siswa dapat mempersiapkan diri dari rumah tentang bahan diskusi adan agar siswa dapat langsung bekerja ketika diberi waktu diskusi.

4. Untuk menyiasati masalah kesulitan siswa menarik kesimpulan dan mengatasi miskonsepsi, guru akan memberikan pertanyaan pancingan kepada siswa dengan menunjuk beberapa siswa untuk menjawab. Keseluruhan dari pernyataan siswa tersebut kemudian disaring dan diberi penjelasan oleh guru jika masih ada yang belum paham. Selanjutnya akan ditarik kesimpulan bersama sehingga siswa bisa lebih mengerti apa yang telah mereka kerjakan dalam kelompok masing-masing.

Pada akhir melaksanakan siklus II, dilakukan tes Formatif II untuk mengetahui pemahaman siswa tentang materi yang diajarkan dengan menerapkan model pembelajaran kooperatif tipe STAD. Hasil Formatif II pada Siklus II disajikan dalam Tabel 4.3. 
Tabel 4.3 Deskripsi Data Formatif II

\begin{tabular}{|c|c|c|}
\hline Nilai & Frekuensi & Rata-rata \\
\hline 60 & 2 & \\
\cline { 1 - 2 } 80 & 4 & \multirow{2}{*}{89} \\
\hline 100 & 9 & \\
\cline { 1 - 2 } Jumlah & 15 & \\
\hline
\end{tabular}

Siklus II dilakukan selama dua KBM yaitu KBM III dan KBM IV. Pada saat melaksanaan KBM dua pengamat merekam aktivitas siswa sesuai dengan instruksi oleh peneliti. Hasil rekaman yang dilakukan oleh pengamat diserahkan kembali kepada peneliti untuk dianalisis. Hasil analisis rekaman aktivitas siswa dari pengamat selama siklus II dapat disajikan dalam Tabel 4.4.

Tabel 4.4 Skor Rata-Rata Aktivitas Belajar Siswa Siklus II

\begin{tabular}{|c|l|c|c|}
\hline No & \multicolumn{1}{|c|}{ Aktivitas } & Skor & Proporsi \\
\hline 1 & Menulis/membaca & 14 & $27 \%$ \\
\hline 2 & $\begin{array}{l}\text { Mengerjakan } \\
\text { LAS }\end{array}$ & 19 & $38 \%$ \\
\hline 3 & $\begin{array}{l}\text { Bertanya pada } \\
\text { teman }\end{array}$ & 12 & $24 \%$ \\
\hline 4 & $\begin{array}{l}\text { Bertanya pada } \\
\text { guru }\end{array}$ & 4 & $9 \%$ \\
\hline & $\begin{array}{l}\text { Yang tidak } \\
\text { relevan dengan } \\
5\end{array}$ & 2 & $3 \%$ \\
\hline \multicolumn{2}{|l|}{ JBM } & 50 & $100.00 \%$ \\
\hline
\end{tabular}

Pada saat kegiatan diskusi berlangsung, dua orang pengamat mengamati aktivitas siswa selama dua siklus. Perubahan aktivitas belajar siswa dari siklus I ke siklus II dapat dilihat lebih jelasnya pada gambar 4.1.



Gambar 4.1 Grafik Aktivitas Belajar Siswa Siklus I dan Siklus II

Keterangan:

1. Menulis,membaca

2. Mengerjakan LAS

3. Bertanya pada teman

4. Bertanya pada guru

5. Aktivitas yang tidak relevan dengan KBM

Terjadi perubahan aktivitas belajar siswa selama dua siklus membawa pengaruh kepada hasil belajar siswa. Adapun perubahan hasil belajar siswa yang siklus I dan siklus II dapat disajikan dalam Gambar 4.2.

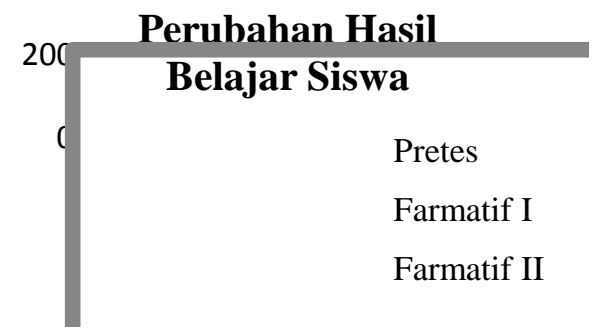

Gambar 4.2 Grafik Perubahan Hasil Belajar Siswa Tiap Siklus 
Merujuk pada Gambar 4.2. peningkatan hasil belajar siswa dari Formatif I dan II menunjukkan ratarata dari 69 menjadi 89. Dengan nilai terendah Formatif I 40 meningkat pada Formatif II menjadi 60 pada siklus II. Nilai tertinggi tetap 100. Dengan ketuntasan klasikal pada Siklus I sebesar $53.33 \%$ dan pada Siklus II sebesar $86.67 \%$, selain terjadi peningkatan pada Siklus II menunjukkan kualitas tuntas secara klasikal karena mencapai $85 \%$ atau dengan kata lain pembelajaran pada kedua Siklus berhasil meningkatkan kualitas hail belajar dan Siklus II mampu atau berhasil mencapai kualitas yang diharapkan.

Pembahasan

Penelitian ini dilaksanakan dalam dua siklus. Masing-masing siklus dilaksanakan dua kali pertemuan, pertemuan digunakan untuk pembahasan materi dengan alokasi waktu 2 x 35 menit, dan sebagian pertemuan akhir siklus digunakan untuk evaluasi dengan alokasi waktu 10 menit. Hal ini disesuaikan dengan jadwal pelajaran matematika. Sebelum dilaksanakan Siklus I dilakukan uji awal untuk menjajaki kemampuan awal siswa. Hasil pretes menunjukkan nilai dengan rata-rata 20 dan nilai terendah 0 diperoleh 1 orang siswa dan tertinggi 30 diperoleh 6 orang siswa. Dengan ketuntasan minimal (KKM) sebesar 75 maka ketuntasan klasikal hanya sebesar $0 \%$.

Setelah diketahui kondisi awal siswa dilanjutkan dengan pelaksanaan siklus I yang dilakukan selama dua KBM yaitu KBM I dan KBM II. Pada saat melaksanakan pembelajaran dua pengamat merekam aktivitas siswa sesuai dengan instruksi oleh peneliti. Hasil rekaman yang dilakukan oleh pengamat diserahkan kembali kepada peneliti untuk dianalisis. Hasil analisis rekaman aktivitas siswa dari pengamat selama siklus I merujuk Tabel 4.2. diperoleh aktivitas yang dominan adalah menulis/membaca dengan proporsi 39\%, kemudian aktivitas mengerjakan LKS dengan proporsi $27 \%$, bertanya pada guru $13 \%$, bertanya pada teman dan yang tidak relevan mendapat proporsi yang sama yaitu $11 \%$. Tingginya aktivitas yang tidak relevan dikarenakan saat pembelajaran berlangsung siswa belum biasa menangkap alur dan konsep yang diberikan guru saat pembelajaran. Hal ini terlihat dari selama proses pembelajaran sebagian siswa hanya sibuk dengan kegiatan mereka masing-masing meskipun guru sudah menegur mereka. Saat presentasi kelompok, masih banyak siswa yang salah dalam menarik kesimpulan.

Kemudian pada akhir siklus I dilakukan tes Formatif I untuk mengetahui kemampuan siswa dalam memahami materi pada siklus I. Nilai hasil Formatif I dalam Siklus I 
merujuk Tabel 4.1. nilai terendah 40 sebanyak 3 siswa dan yang mendapat nilai 100 sebanyak 2 orang. Nilai rata-rata 69 dengan KKM 75, jumlah siswa tuntas 8 dari 15 siswa. Hal ini menunjukkan hasil belajar siswa masih rendah. Hasil tersebut menunjukkan bahwa pada Siklus I secara klasikal, siswa belum tuntas belajar, karena siswa yang memahami materi yang telah disampaikan hanya sebesar $53.33 \%$ lebih kecil dari persentase ketuntasan yang dikehendaki yaitu sebesar $85 \%$.

Merujuk pada hasil belajar, aktivitas belajar dan dokumentasi penelitian, belum tercapainya hasil belajar siswa pada ketuntasan klasikal disebabkan oleh :

1. Sebagian siswa masih belum terbiasa dengan alur pembelajaran atau masih bingung selama pelaksanaan kegiatan.

2. Sebagian siswa belum memiliki rasa tanggung jawab terhadap tugasnya dalam kelompok, di setiap kelompok siswa masih ada anggota kelompok yang menyerahkan permasalahan kepada anggota kelompoknya dan tidak mau tau, bahkan ada beberapa siswa yang menciptakan kegaduhan dalam kelompoknya.

3. Terlalu singkat waktu diskusi yang diberikan sehingga aktivitas diskusi tampak terburu-buru, apalagi waktu diskusi terpakai untuk kelompok mempelajari
LAS, sehingga waktu pengerjaan LAS semakin sedikit.

4. Masih terjadi kesalahankesalahan dalam mengerjaan LAS dan penarikan kesimpulan oleh siswa yang menandakan terjadi miskonsepsi dalam diskusi kelompok.

Sebelum melanjutkan siklus II, peneliti berdiskusi dengan guru sejawat dan pengamat untuk memperbaiki proses pembelajaran supaya siklus II dapat berhasil meningkatkan hasil belajar dan aktivitas siswa. Hasil diskusi perbaikan yang akan dilakukan pada Siklus II adalah sebagai berikut:

1) Untuk membantu siswa menyesuaikan diri dalam alur pembelajaran maka sebelum pembelajaran berlangsung guru akan menjelaskan terlebih dahulu desain pembelajaran sesuai dengan model pembelajaran kooperatif tipe STAD.

2) Untuk memunculkan rasa tanggung jawab masing-masing siswa maka tiap kelompok dibantu dalam membagi spesifikasi siswa dalam tugas masing-masing dan memberi peringatan bahwa tiap siswa akan ditagih pekerjaanya dalam kegiatan bertanya.

3) Untuk menyiasati masalah waktu, maka guru akan membagikan LAS sebelum KBM dilaksanakan. Hal ini agar siswa 
dapat mempersiapkan diri dari rumah tentang bahan diskusi adan agar siswa dapat langsung bekerja ketika diberi waktu diskusi.

4) Untuk menyiasati masalah kesulitan siswa menarik kesimpulan dan mengatasi miskonsepsi, guru akan memberikan pertanyaan pancingan kepada siswa dengan menunjuk beberapa siswa untuk menjawab. Keseluruhan dari pernyataan siswa tersebut kemudian disaring dan diberi penjelasan oleh guru jika masih ada yang belum paham. Selanjutnya akan ditarik kesimpulan bersama sehingga siswa bisa lebih mengerti apa yang telah mereka kerjakan dalam kelompok masing-masing.

Setelah diketahui tindakan perbaikan, maka peneliti melanjutkan penelitian ke siklus II yang dilakukan selama dua KBM yaitu KBM III dan KBM IV. Pada saat melaksanaan KBM dua pengamat merekam aktivitas siswa sesuai dengan instruksi oleh peneliti. Hasil rekaman yang dilakukan oleh pengamat diserahkan kembali kepada peneliti untuk dianalisis. Hasil analisis rekaman aktivitas siswa dari pengamat selama siklus II merujuk Tabel 4.4. dimana aktivitas yang dominan adalah mengerjakan LAS dengan proporsi 38\%, kemudian dilanjutkan dengan menulis/membaca (27\%), bertanya pada teman $(24 \%)$, bertanya pada guru (9\%) dan yang aktivitas yang paling rendah adalah aktivitas yang tidak relevan dengan KBM mencapai proporsi $3 \%$.

Kemudian pada akhir melaksanakan siklus II, dilakukan tes Formatif II untuk mengetahui pemahaman siswa tentang materi yang diajarkan dengan menerapkan model pembelajaran kooperatif tipe STAD. Hasil Formatif II pada Siklus II merujuk Tabel 4.3. dengan nilai terendah 60 sebanyak 2 siswa dan yang mendapat nilai 100 sebanyak 9 orang. Nilai rata-rata 89 dengan KKM 75, jumlah siswa tuntas 13 dari 15 siswa. Hal ini menunjukkan hasil belajar siswa sudah meningkat. Hasil tersebut menunjukkan bahwa pada Siklus II secara klasikal siswa sudah tuntas belajar, karena siswa yang memahami materi yang telah disampaikan sebesar $86.67 \%$ lebih besar dari persentase ketuntasan yang dikehendaki yaitu sebesar $85 \%$. Peningkatan hasil belajar ini disebabkan karena guru memberikan siswa tugas di rumah yang bertujuan supaya siswa mengulang pelajaran. Hal ini membuat siswa semakin memahami pembelajaran.

Dengan demikian secara keseluruhan dapat dikatakan bahwa proses pembelajaran menggunakan model pembelajaran kooperatif tipe STAD dapat meningkatkan ketuntasan pembelajaran siswa pada 
pembelajaran matematika di kelas III SD Negeri No. 056591 Sidorejo dan berhasil memberi ketuntasan klasikal sampai pada akhir Siklus II. Keadaan tersebut dapat dijadikan sebagai kajian bahwa dengan Siklus yang berulang dan menggunakan model pembelajaran kooperatif tipe STAD memungkinkan meningkatkan ketuntasan pembelajaran matematika siswa. Namun demikian penelitian hanya dilaksanakan sampai pada dua Siklus karena keterbatasan dana dan waktu.

\section{SIMPULAN}

Berdasarkan analisis data dan pembahasan, maka dapat disimpulkan penerapan model pembelajaran kooperatif tipe STAD dalam pembelajaran matematika di kelas III SD Negeri No. 056591 Sidorejo Tahun Pembelajaran 2015/2016 bahwa :

1. Hasil belajar siswa meningkat dari siklus I ke siklus II setelah menerapkan model pembelajaran kooperatif tipe STAD. Pada siklus I terdapat 8 siswa yang tuntas secara individu tetapi kelas belum tuntas sedangkan pada siklus II terdapat 13 siswa yang tuntas secara individu dan tuntas secara kelas. Peningkatan terjadi karena guru memberikan tugas kepada siswa untuk dikerjaan di rumah, hal ini membuat siswa semakin memahami pembelajaran.
2. Terjadi peningkatan rata-rata aktivitas belajar siswa menurut dua pengamat dari siklus I ke siklus II. Aktivitas yang meningkat adalah aktivitas mengerjakan LAS dari $27 \%$ menjadi $38 \%$ dan bertanya pada teman dari $11 \%$ menjadi $24 \%$, sedangka aktivitas yang menurun adalah menulis/ membaca dari $39 \%$ menjadi $27 \%$, aktivitas aktivitas bertanya pada guru dari 13\% menjadi 9\% dan aktivitas yang tidak relevan dengan KBM dari $11 \%$ menjadi $3 \%$. Peningkatan aktivitas terjadi karena setiap siswa sudah memiliki tanggung jawab masing-masing sehingga pembelajaran berjalan sesuai yang diharapkan.

\section{DAFTAR RUJUKAN}

Aqib, Zainal. 2006. Penelitian Tindakan Kelas. Bandung: Penerbit Yrama Widya.

Lie, Anita. 2008. Cooperatif Learning. Jakarta: Grasindo.

Slavin, Robert E. 2005. Cooperative Learning; Teori, Riset, dan Praktik. Bandung: Nusa Media.

Suwandi, Sarwiji dan Madyo Ekosusilo. 2007. Pendidikan dan Latihan Profesi Guru (PLPG). Surakarta: Panitia Sertifikasi Guru Rayon 13. 